UDC 539.3

\title{
THE STABILITY OF ROTATING RODS UNDER THE ACTION OF VIBRO-IMPACT LOAD
}

\author{
P.P. Lizunov, \\ Doctor of Technical Science \\ V.O. Nedin, \\ Candidate of Technical Science \\ Kyiv National University of Construction and Architecture, \\ 31, Povitroflotskiy avenue, Kyiv, Ukraine
}

DOI: $10.32347 / 2410-2547.2021 .106 .113-121$

\begin{abstract}
The paper presents the investigation results of the vibro-impact loads' influence on the stability of vibro-drilling machine' drill-rod in the process of well in hard rock. The drilling process of such wells is significantly facilitated in case of vibro-impact action. The destroying of the rocks during the vibro-rotary drilling occurs via the complex effect of the vibration impulses and rotational motion. In this way, the task of such drill-rod study stability has actuality. In this case, the various modes of vibration and stability loss are possible. In this regard, the study was done by developed software, in which a technique of computer simulation of the oscillating motion of considerable length rotating rods under the action of axial periodic loads is implemented. Such software gives the possibility to model the oscillatory motion of rotating rods and determine the parameters by witch the dynamic stability loss of the studied system can occur. Using this software the diagrams with regions of stable and unstable motion of the rotating rod were drawn for different parameters of the considered system. The process of oscillation is considered in space with account of inertia forces and geometric nonlinearity of the rod. It is shown, that on certain rotational speeds and frequencies of vibro-impact load there are ranges of unstable motion where the run of equipment can inevitably lead to destruction. The obtained results have been analyzed. The conclusion about the possibility of running the equipment in certain frequency ranges is made.

Keywords: numeric differentiation, complex bend forms, geometric nonlinearity, inertia forces, axial forces, vibro-impact loads, vibro-drilling, dynamic stability.
\end{abstract}

Introduction. The tasks of dynamics of rotating rods and rods under the action of axial periodic and impact loads have been studied by many authors. The statics and dynamics of the rod under axial loading are considered in paper [9]. The conditions for the parametric resonances appearance have been studied and the possibility of stability loss under load less than Euler force has been found. In paper [10], the dynamics of the rod during a short-term axial impact is considered. The conditions for the parametric resonance are found in the linear statement. The regions of instability in "length of the rod - loads" field are constructed and the characteristic parameters are calculated. The problem of impact by an elastic body at the end of an elastic rod is studied in paper [3]. Depending on the task parameters, the time and form of an impact impulse and the maximum amplitude of transverse oscillations by parametric resonance are theoretically and experimentally determined. In paper [4], the task of the dynamic stability of a hinged rod in case of sharp axial load is reviewed. The method of series expansion according to the forms of nature oscillations for both longitudinal and transverse oscillations is applied.

(C) Lizunov P.P., Nedin V.O. 
Instability regions are shown. The type of these regions depends on the spectral properties of longitudinal and transverse oscillations, values of damping and axial force. The axial impact on a thin elastic rod is considered in paper [5], which generates a periodic system of longitudinal waves in it. A strict analysis of solution is done and the value of the maximum transverse bend depended on the method of loading is found. Both, the short-term and long-term impulses are considered. In the case of suddenly applied long impulse that is less than the Euler critical force, is shown, that the development of intensive transverse oscillations is possible.

The results of numerical studies of the dynamic behavior of vibro-impact system are presented in study [1]. This system is strongly nonlinear and nonsmooth discontinuous dynamic system. The results of observations of many interesting phenomena, in particular those that are unique to non-smooth systems, are presented. Regions of stable and unstable motions were found using the solution continuation method by parameter and Floke multipliers. The breaking bifurcations, hysteresis effect, scenarios of quasi-periodic transition to chaos and transition to chaos through intermittency, transient chaos, boundary crisis, rare attractor, transient modes are described. A comparative analysis of impact simulation methods in vibro-impact systems with hard and soft impact is performed.

The oscillations of rotating rods under the action of periodic loads were considered in other papers. The paper [11] presents the results of study of space bending oscillations of horizontal rod that is rotating around its axis. Rod is under the action of periodic harmonic force of self-weight per length. The task is considered taking into account gyroscopic loads, but rod is located horizontally.

In paper [14], the influence of periodic impact loads on the structural elements of drill string during longitudinal oscillations is investigated. The results reveal that a periodic impulse can mainly be determined by the nature of the rock and the impact frequency during the drilling.

In paper [16], the problem of drilling system dynamics with account of axial periodic force of impact action is considered in a nonlinear statement. The research was performed to study the vibrations that occur in the coupling. The simulations of dynamic model are researched with conditions for different hardness of rock. The results indicate that the transverse and longitudinal vibration frequencies and amplitude decrease with the rock hardness.

In paper [13], the results of investigation of the oscillations of long rotating rod are shown. The rod is modeling the drill string operation. Results are shown by possible bend forms at different moments of time after system had been out of equilibrium. It is noted that the action of an axial compressive force that is pointed to the lower end of the vertical heavy rod leads to the effect of twisting to a spiral of its lower part. This effect arises via action of gyroscopic moments, which begin to appear when the lower part of the rod starts to bend and this bending have been growing. 
Paper [8] presents the results of numerical investigation of the periodic axial forces' influence on the transverse oscillations of long rotating rods. The gyroscopic inertia forces are taken to account and space oscillating process of rotating rods is considered with account of geometric nonlinearity. For investigated objects is shown that on various rotational speeds and beat frequencies the oscillatory motion of the rods occurs with different character of behavior. On certain speeds with different frequencies of axial load the oscillations have definite periodicity and occur with beats of amplitude which are the result of the periodic axial force action.

The paper [12] presents the results of investigation of the axial beat loads' influence on the transverse rotating rods' oscillations and their stability. The perforator's long drills are considered as objects of investigation. Diagrams with regions of stable and unstable motion of the rods, that were found by different parameters and boundary conditions are shown.

In this paper the dynamic behavior of vibro-drilling machine' drill-rod under action of axial impact load is investigated. Such tasks arise when the wells drill through hard rocks or grounds with inclusions of large fragments of rocks. The drilling process of these wells is significantly facilitated in the case of vibro-impact action. Since the destruction of the rock during such drilling occurs via the complex effect of the vibration impulses and rotational motion, the task of such drill-rod study stability has actuality, namely, at what rotational speeds and frequencies of vibro-impact loads the loss of stability can happened and the run of equipment can lead to its failure.

In addition to the impact load for such rods, the loss of stability is significantly influenced by own weight forces, which have a compressive nature of the load. It is due to the boundary conditions of the vertical positioned rod.

In study the dynamics of considered objects, it is interesting to note the parametric oscillations of rods under the action of periodic axial impact loads during rotation. This is due to the actuality of the vibratory drilling tasks.

Problem statement. In the process of oscillation of rotating rods, under the action of external periodic impact forces, the various character of the oscillatory motion are possible. It is depended on different physical, geometric and dynamic parameters.

As a dynamic model is considered rod with length $l$ (Fig. 1) that is exposed by the action of periodic vibro-impact load $P(t)$.

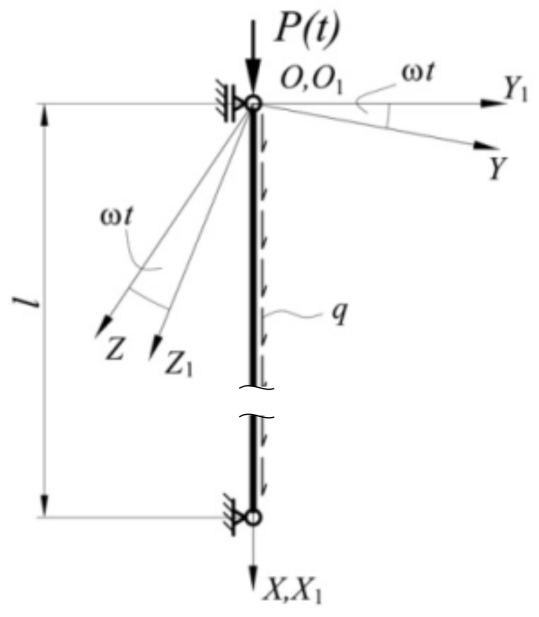

Fig. 1. Dynamic model of system 
The rod is under the action of longitudinal load of own weight $q$ and rotates on angular speed $\omega$ around the rectilinear axis $O_{1} X_{1}$ of the stationary coordinate system $O_{1} X_{1} Y_{1} Z_{1}$. The rotating coordinate system $O X Y Z$ is tied to the rod and rotates with it. The oscillatory motion of the rod in the $O X Y Z$ coordinate system is characterized by $y(x, t)$ and $z(x, t)$ displacements of the points, that belong to the axis of rod in the $O Y$ та $O Z$ coordinate axes' direction, respectively.

The oscillations of rotating vertical rod in space coordinate system $O X Y Z$ are described by the corresponding system of differential equations, which taking into account the inertia forces, own weight and the axial periodic force have a form $[6,12]$ :

$$
\left\{\begin{array}{l}
\frac{d^{2}}{d x^{2}}\left(\frac{E I_{1(x)}}{\rho_{1}}\right)-\bar{m} r^{2}\left(\frac{d^{4} y}{d t^{2} d x^{2}}+\omega^{2} \frac{d^{2} y}{d x^{2}}\right)-2 \omega \bar{m} \frac{d z}{d t}-\bar{m} \omega^{2} y+\bar{m} \frac{d^{2} y}{d t^{2}}+ \\
+P(t) \frac{d^{2} y}{d x^{2}}+\frac{1}{d x}\left(\bar{m} g(l-x) \frac{d y}{d x}\right)=0, \\
\frac{d^{2}}{d x^{2}}\left(\frac{E I_{2(x)}}{\rho_{2}}\right)-\bar{m} r^{2}\left(\frac{d^{4} z}{d t^{2} d x^{2}}+\omega^{2} \frac{d^{2} z}{d x^{2}}\right)+2 \omega \bar{m} \frac{d y}{d t}-\bar{m} \omega^{2} z+\bar{m} \frac{d^{2} z}{d t^{2}}+ \\
+P(t) \frac{d^{2} z}{d x^{2}}+\frac{1}{d x}\left(\bar{m} g(l-x) \frac{d z}{d x}\right)=0,
\end{array}\right.
$$

where $E$ - elastic modulus of rod's material; $I_{1(x)}, I_{2(x)}$ - inertia moments of rod section in mutually perpendicular planes; $r$ - radius of gyration; $\bar{m}$ - mass of unit per length; $1 / \rho_{1}, 1 / \rho_{2}$ - main curvatures of rod's axis in mutually perpendicular planes.

The action of vibro-impact load is modeled by $P(t)$ function [12].

Technique. To study of the dynamics of investigated objects in this paper the technique that is described in papers $[7,12]$ is used. In this technique the process of oscillation is modeled based on repeated (cyclic) solving the system of differential equations for every point of system in order to find the new coordinates of positions for these points in each next point of time $t+\Delta t$.

The technique is realized by computer program with graphic user interface that is developed by authors. That program lets to study the dynamics of modeled system by calculating and drawing the current bend forms of the rotating rod in oscillation. Also, program lets to make the analysis of behavior of modeled system, find the dynamic instability regions, draws the diagrams of it.

Results. In this paper, using said program, the study of the dynamics of the drill-rod under the action of axial vibro-impact load is done. The operation of vibro-drilling machine in range of rotational speeds $n=40-65 \mathrm{rpm}$ and range of impact frequencies $\theta=100 \ldots 150 \mathrm{~s}^{-1}$ is considered. The rod of the work body is tubular, with outer diameter $d=146 \mathrm{~mm}$, wall thickness $s=8 \mathrm{~mm}$. Reviewed operation depth of well in range $20 \ldots 40 \mathrm{~m}$.

As results of study of investigated objects in Figures 2-5 the fields of stable and unstable oscillations are presented. These fields show unstable regions in 
depends of rotational speeds $\omega$ and impact frequencies $\theta$, which were found for the reviewed objects with different length of rod.

The fields of unstable oscillations are displayed filled gray. White colored regions are the fields of stable motion.

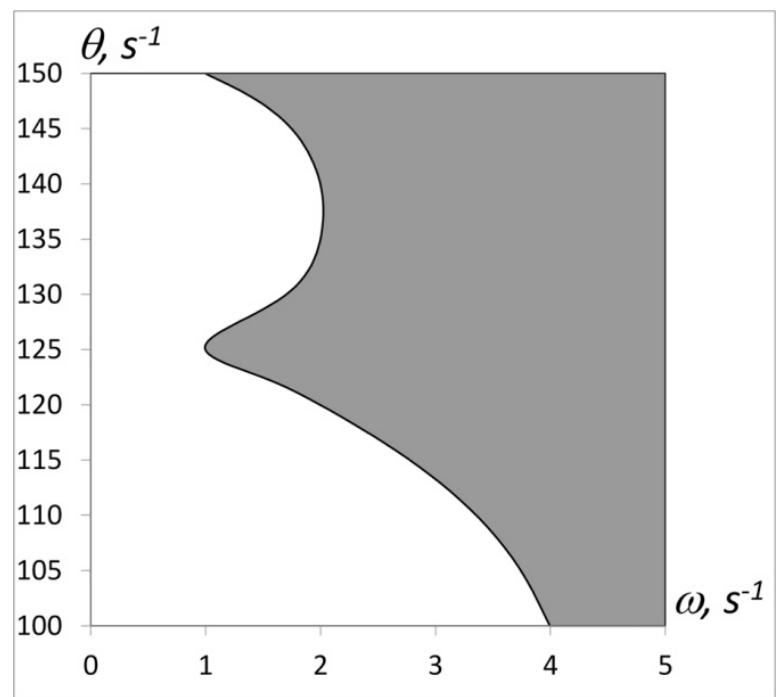

Fig. 2. Dynamic stability fields of drill-rods with length $l=20 \mathrm{~m}$, under action of axial vibro-impact load $P(t)$

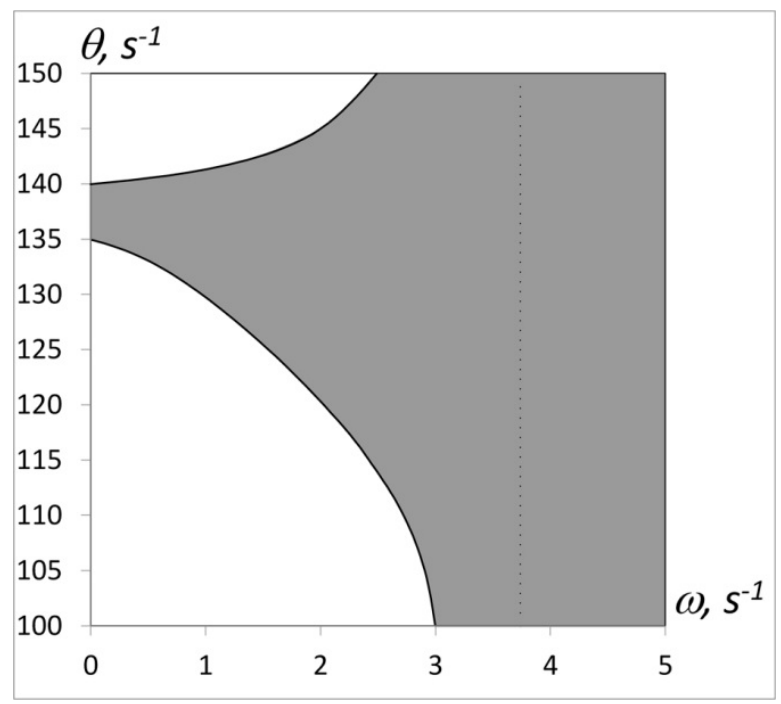

Fig. 3. Dynamic stability fields of drill-rods with length $l=25 \mathrm{~m}$, under action of axial vibro-impact load $P(t)$ 
As we can see from diagrams, for various length of rod with their parameters, there are fields of unstable oscillation motion. Than longer the rod, that larger the area of this field.

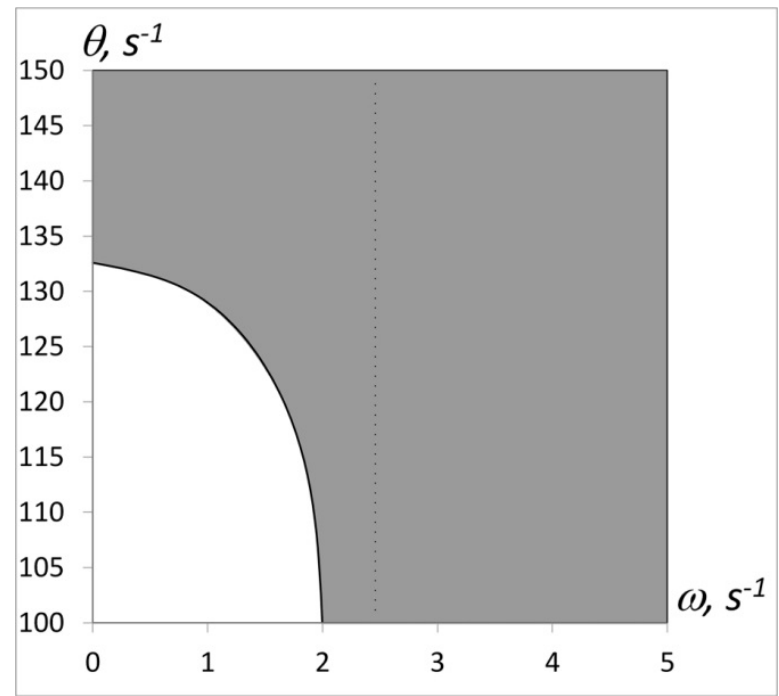

Fig. 4. Dynamic stability fields of drill-rods with length $l=30 \mathrm{~m}$, under action of axial vibro-impact load $P(t)$

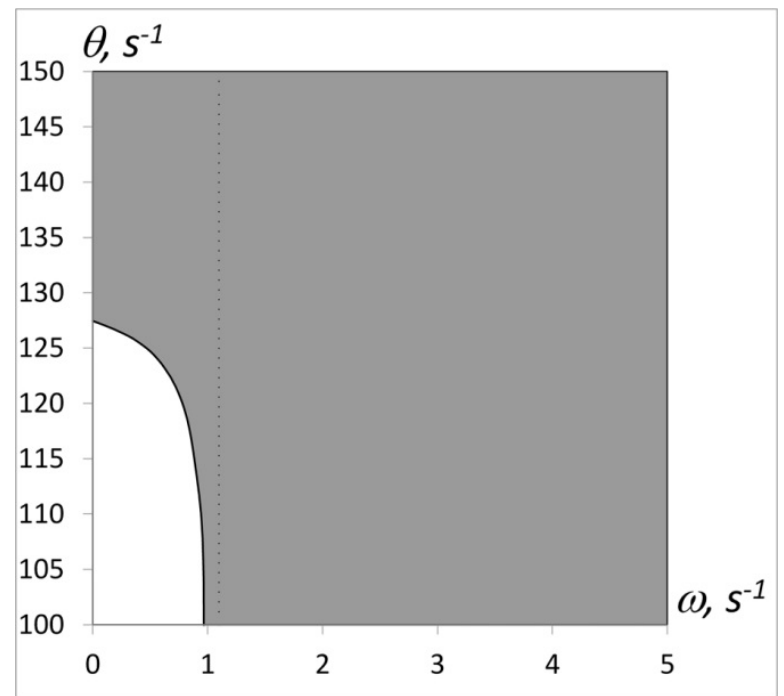

Fig. 5. Dynamic stability fields of drill-rods with length $l=40 \mathrm{~m}$, under action of axial vibro-impact load $P(t)$ 
Common for these diagrams is that that with growth of rotational speed the limit value of the frequency of the impact load, at which the stable oscillation is possible, reduce.

For shorter rods $(20,25 \mathrm{~m})$ there are ranges of vibro-impact load frequencies at which the limit value of frequency can growth at certain range of rotational speeds.

For the rod with length $l=20 \mathrm{~m}$ there is frequency range of vibro-impact load $\theta\left(135 \ldots 140 \mathrm{~s}^{-1}\right)$, at which the instability can occur when the rotational speed is equal to 0 . For longer rods that range can lie in lower values of $\theta$ and exists in the operated range of those frequencies.

Conclusion. The presented researches results of axial vibro-impact loads influence on stability of rotating drill-rods show that on certain rotational speeds and frequencies of vibro-impact loads there are regions of unstable motion, where the run of equipment can inevitably lead to destruction. Secure operation of the equipment is possible in the frequency ranges which are in the fields of stable oscillations that are shown on diagrams for different lengths of drill-rod.

\section{REFERENCES}

1. Bazhenov V.A., Pohorelova O.S., Postnikova T.G. Khaos ta stsenariyi perekhodu do khaosu u vibroudarniy systemi. - Kyiv: Vyd-vo «Karavela», 2019. - 146 p.p.

2. Bakhvalov N.S., Judkov N.P., Kobelkov G.M. Chislennye metody. M.: BINOM, Laboratoriya znaniy, 2015, $639 \mathrm{pp}$.

3. Belyaev A. Dynamics of rod under axial impact by a body / Alexander K. Belyaev, ChienChing Ma, Nikita F. Morozov, Petr E. Tovstik, Tatiana P. Tovstik, Anatoly O. Shurpatov // Vestnik SPbGU. Matematika. Mekhanika. Astronomiya. - 2017. V. 4 (62). -P. 506-515.

4. Belyaev A. Dinamicheskiy podkhod k zadache Ishlinskogo-Lavrent'yeva / A.K. Belyayev, D.N. Il'in, N.F. Morozov // Mekhanika tverdogo tela. - 2013. No. 5. - P. 28-33.

5. Belyaev A. Parametric resonances in the problem of longitudinal impact on a thin rod / Alexander K. Belyaev, Nikita F. Morozov, Petr E. Tovstik, Tatiana P. Tovstik // Vestnik SPbGU. Matematika. Mekhanika. Astronomiya. - 2016. V. 3 (61). - P. 77-94.

6. Bolotin V.V. Dinamicheskaya ustoychivost uprugih system. M.: Izdatelstvo tekhnikoteoreticheskoj literatury, $1956,600 \mathrm{pp}$.

7. Lizunov P.P., Nedin V.O. The gyroscopic forces influence on the oscillations of the rotating shafts // Strength of materials and theory of structures. - 2020. - Issue 105. P. 223-231.

8. Lizunov $P$., Nedin $V$. The parametric oscillations of rotating elastic rods under the action of the periodic axial forces // Management of Development of Complex Systems. - 2020, 44, 56-64.

9. Morozov N.F. Static and Dynamics of a Rod at the Longitudinal Loading / N.F. Morozov, P.E. Tovstik, T.P. Tovstik // Vestnik YUUrGU. Seriya «Matematicheskoye modelirovaniye i programmirovaniye». - 2014. - Vol. 7, No. 1. - S. 76-89.

10. Morozov N.F. The rod dynamics under short longitudinal impact / N.F. Morozov, P.E. Tovstik // Vestnik SPbGU. - 2013. - Vup. 3. P.131-141.

11. Munitsyn A.I. Prostranstvennyye izgibnyye kolebaniya sterzhnya, vrashchayushchegosya vokrug svoyey osi (Space bending oscillations of a rod rotating around its axis) // Matematicheskoye i komp'yuternoye modelirovaniye mashin i sistem. -2008. S. 64-67.

12. Nedin V.O. The parametric oscillations of rotating rods under action of the axial beat load // Strength of materials and theory of structures. - 2020. - Issue 104. P. $309-320$.

13. Nedin $V$. Numerical differentiation of complex bend forms of long rotating rods // Management of Development of Complex Systems. - 2020, 43, 110 - 115 .

14. Changgen $B u$. Arithmetic solution for the axial vibration of drill string coupling with a downthe-hole hammer in rock drilling / Changgen Bu, Xiaofeng Li, Long Sun and Boru Xia // Journal of Vibration and Control. - 2016, Vol. 22(13). - P. 3090-3101. 
15. Maurice Petyt. Introduction to Finite Element Vibration Analysis. Cambridge University Press, 1990. $-558 \mathrm{p}$.

16. Songyong Liu. Coupling vibration analysis of auger drilling system / Songyong Liu, Xinxia Cui, Xiaohui Liu // Journal of vibroengineering. - 2013. Vol. 15. - P.1442-1453.

17. Yimin Wei. Influence of Axial Loads to Propagation Characteristics of the Elastic Wave in a Non- Uniform Shaft / Yimin Wei, Zhiwei Zhao, Wenhua Chen and Qi Liu // Chinese Journal of Mechanical Engineering. - 2019- No. 32:70. P.13.

Стаття надійшла 26.04.2021

Лізунов П.П., Недін В.О.

\section{СТІЙКІСТЬ СТЕРЖНІВ, ЩО ОБЕРТАЮТЬСЯ, ПІД ДІЕЮ ВІБРОУДАРНОГО НАВАНТАЖЕННЯ}

В роботі наведені результати дослідження впливу віброударних навантажень на стійкість стержня робочого органа вібробурового агрегату при бурінні свердловин в твердих породах грунту. Процес буріння таких свердловин суттєво полегшується у разі віброударного впливу. Руйнування породи при вібраційно-обертальному бурінні відбувається через спільний вплив віброударних імпульсів і обертального руху. У зв'язку 3 цим, актуальним $є$ питання стійкості стержня робочого органа такої установки при обертанні. При цьому можливі різноманітні форми коливань і втрати стійкості. У зв'язку 3 цим дослідження здійснено використовуючи розроблене програмне забезпечення, в якому реалізована методика комп'ютерного моделювання коливального руху стержнів значної довжини, що обертаються, під дією поздовжніх періодичних навантажень. Таке програмне забезпечення дозволяє моделювати коливальний рух стержнів, що обертаються, а також визначати параметри, при яких відбувається втрата динамічної стійкості змодельованої системи. За допомогою зазначеного програмного забезпечення побудовані діаграми, що відображають області стійкого та нестійкого руху стержня, яким моделюється робочий орган вібробурової установки, при різних параметрах системи. Процес коливального руху розглянуто у просторі з урахуванням інерційних навантажень та геометричної нелінійності стержня. Показано, що при певних значеннях швидкостей обертань і частот дії віброударного навантаження існують області нестійкого руху, при яких експлуатація обладнання може неминуче привести до його руйнування. Здійснено аналіз отриманих результатів та зроблено висновок про можливість експлуатації обладнання у певних діапазонах частот.

Ключові слова: чисельне диференціювання, складні форми вигину, геометрична нелінійність, інерційні навантаження, поздовжні навантаження, ударні навантаження, вібробуріння, динамічна стійкість.

\section{Лизунов П.П., Недин В.О.}

\section{УСТОЙЧИВОСТЬ ВРАЩАЮЩИХСЯ СТЕРЖНЕЙ ПОД ДЕЙСТВИЕМ ВИБРОУДАРНОЙ НАГРУЗКИ}

В работе приведены результаты исследования влияния виброударных нагрузок на устойчивость стержня рабочего органа вибробурового агрегата при бурении скважин в твердых породах грунта. Процесс бурения таких скважин существенно облегчается при виброударном воздействии. Разрушение породы при вибрационно-вращательном бурении происходит при совместном влиянии виброударных импульсов и вращательного движения. В связи с этим, актуальной задачей является изучение устойчивости стержня рабочего органа такой установки при вращении. При этом возможны различные формы колебаний и потери устойчивости. В связи с этим исследование проведено с использованием разработанного для этих целей программного обеспечения, в котором реализована методика компьютерного моделирования колебательного движения вращающихся стержней значительной длины, под действием продольных периодических нагрузок. Такое программное обеспечение позволяет моделировать колебательное движение вращающихся стержней, а также определять параметры, при которых происходит потеря динамической устойчивости смоделированной системы. $\mathrm{C}$ помощью указанного программного обеспечения построены диаграммы, отображающие области устойчивого и неустойчивого движения стержня, которым моделируется рабочий орган вибробурильной установки при 
различных параметрах системы. Процесс колебательного движения рассмотрен в пространстве с учетом инерционных нагрузок и геометрической нелинейности стержня. Показано, что при определенных скоростях вращения и частот действия виброударной нагрузки существуют области неустойчивого движения, при которых эксплуатация оборудования может неизбежно привести к его разрушению. Проанализированы полученные результаты и сделан вывод о возможности эксплуатации оборудования в определенных диапазонах частот.

Ключевые слова: численное дифференцирование, сложные формы изгиба, геометрическая нелинейность, инерционные нагрузки, продольные нагрузки, ударные нагрузки, вибробурение, динамическая устойчивость.

\section{УДК 539.3}

Лізунов П.П., Недін В.О. Стійкість стержнів, що обертаються, під дією віброударного навантаження // Опір матеріалів і теорія споруд: наук.-тех. збірн. - К.: КНУБА, 2021. Вип. 106. - С. 113-121.

В роботі наведені результати дослідження впливу поздовжніх віброударних навантажень на стійкість стержнів, якими моделюється робота вібробурильного агрегаmy

Табл. 0. Іл. 5. Бібліогр. 17 назв.

\section{UDC 539.3}

Lizunov P.P., Nedin V.O. The stability of rotating rods under the action of vibro-impact load // Strength of Materials and Theory of Structures: Scientific-\&-Technical collected articles. - Kyiv: KNUBA, 2021. - Issue 106. - P. 113-121.

The paper presents the results of investigation of the axial vibro-impact loads' influence on the stability of rods that the vibro-drilling machine work body is modeled.

Tabl. 0. Fig. 5. Ref. 17.

\section{УДК 539.3}

Лизунов П.П., Недин В.O. Устойчивость вращающихся стержней под действием виброударной нагрузки // Сопротивление материалов и теория сооружений. - 2021. - Вып. 106. - С. 113-121.

В работе представлены результаты исследования влияния продольных виброударных нагрузок на устойчивость стержней, которыми моделируется работа вибробурильного агрегата.

Табл. 0. Ил. 5. Библиогр. 17 назв.

Автор (науковий ступень, вчене звання, посада): доктор технічних наук, професор, завідувач кафедри основ інформатики КНУБА, ЛІЗУНОВ Петро Петрович.

Адреса робоча: 03037 Украӥна, м. Київ, Повітрофлотський проспект 31, КНУБА, кафедра основ інформатики, ЛІЗУНОВ Петро Петрович.

Адреса домашня: Украӥна, м. Київ, вул. Кавказька, 12, кв. 48.

Мобільний тел.: +38(067) 921-70-05

E-mail: lizunov@knuba.edu.ua

ORCID ID: http://orcid.org/0000-0003-2924-3025

Автор (вчена ступень, вчене звання, посада): кандидат технічних наук, доцент кафедри основ інформатики КНУБА, НЕДІН Валентин Олегович.

Адреса робоча: 03680 Украӥна, м. Київ, Повітрофлотський проспект 31, Київський національний університет будівництва і архітектури, НЕДІН Валентин Олегович.

Адреса домашня: 04213 Украӥна, м. Київ, вул. Північна 50, кв. 181, НЕДІН Валентин Олегович.

Роб. тел.: +38(044) 241-54-62;

мобільний тел.: +38(067) 764-95-52;

E-mail: nedin.vo@knuba.edu.ua

ORCID ID: http://orcid.org/0000-0003-3138-2892 